\title{
Learning about Microorganisms in Childhood: Four- to Six-Year-Old Children's Voice in Kindergartens and Museums
}

\author{
Aprendizagem sobre Microrganismos na Infância: a Voz de \\ Crianças de 4 a 6 anos em Creches e Museus
}

\author{
Celi Rodrigues Chaves Dominguez ${ }^{\circledR}$ Brazil \\ Natalia Leporo Brazil \\ Milene Tino De Franco ${ }^{-1}$ Brazil \\ Glaucia Colli Inglez ${ }^{\circledR}$ Brazil \\ Viviane Maimoni Gonçalves ${ }^{\circ}$ Brazil \\ Alessandra Fernandes Bizerra ${ }^{\circledR}$ Brazil
}

The main purpose of this research was to identify 4 to 6-year-old children's ideas about microorganisms, taking into consideration the learning processes carried out in different educational contexts. To this end, data were collected from two institutions - a science museum and a kindergarten - by means of interviews, recorded conversations, drawings, and the application of a didactic sequence with the kindergarten group. A qualitative analysis of the data revealed that children associate the presence of microorganisms with dirty places and see them as pathological agents. The children demonstrated that they understand the idea of scale and the need for magnifying instruments. We found that they consider microorganisms morphologically similar to insects and that they use various scientific words appropriately. It was concluded that young children understand the theme "microorganisms", and that it should be addressed more actively by institutions that teach four- to six-year-olds, which are responsible for contributing to their scientific literacy and science learning in childhood. It is proposed that the following themes be developed in educational activities with young children: biodiversity, scale, biological functions, and relationships with humans and food.

Keywords: science education; early childhood education; science museums; microorganisms.

Esta pesquisa teve como principal finalidade identificar as ideias de crianças entre quatro a seis anos de idade acerca do conhecimento que possuem sobre microrganismos. Os dados foram coletados em duas instituições: um museu de ciências e uma creche. Para tal, foram realizadas entrevistas, registros de conversas, coleta de desenhos, além da 
aplicação de uma sequência didática com o grupo da creche. A análise qualitativa dos dados revelou que as crianças associam a presença dos microrganismos a lugares sujos e como agentes patológicos. Foi observado que as crianças são capazes de compreender a ideia de escala e a necessidade do uso de instrumentos de ampliação. Elas supõem que os microrganismos assemelham-se, morfologicamente, aos insetos e utilizam adequadamente de vários vocábulos científicos. Concluiu-se que o tema "microrganismos" pode ser compreendido pelas crianças pequenas e que deve ser mais abordado pelas instituições que atendem o público na faixa de quatro a seis anos e que têm a responsabilidade de contribuir com sua alfabetização científica. Propõe-se que os seguintes eixos sejam desenvolvidos em ações educativas com crianças pequenas: biodiversidade, escala, função biológica, relação com seres humanos e alimentação.

Palavras-chave: educação em ciências; educação infantil; museus de ciências; microorganismos.

\section{Introduction}

How would children of an early age face issues of scientific concern? There are not many inquiries that have dealt with this question. Investigations, as the ones carried out by Dominguez (2001), Goulart (2005) and Siry, Ziegler, and Max (2012), that deepen discussions about 'whether' and 'how' very young children can learn concepts related to scientific knowledge, are rare.

The same situation can be found considering the subject of "microorganisms". Also, most researchers have directed their attention to adults or older children (Helman, 1978; Souza, 2009; Trivelato, 2005). Although there are works that investigates how children understand microorganisms, they are generally targeted at children over six years of age (White, Elsom, \& Prawat, 1980; Miguel, 2010; Byrne, Grace, \& Hanley, 2009; Byrne, 2011). It is relevant to note that, in addition to the fact that there is little research related to the conceptions of young children on microorganisms, none of the references analyzed is related to science museums or scientific exhibitions with this theme.

Thus, the first challenge of creating and mounting an exhibition in a science museum aimed at a specific audience of children aged four to six was to determine the ideas they had of the microscopic world in order to provide a significant and proper interaction between children and the museum during visiting hours. In an attempt to understand this question, the present research approaches those that seek to understand the content and nature of student conceptions, as well as how these conceptions can both hinder and contribute to learning. As noted from the extensive compilation conducted by Duit (2009), involving research on conceptions about scientific issues of students and teachers, the theme is strongly present in the science education literature since the 1970s. According to Tsai and Wen (2005), the research topic of students' conceptions and conceptual change was the most frequently investigated one from 1998 to 2002. Furthermore, although in the next five years the focus of research on science learning has 
changed from student conception and conceptual change to student learning contexts, conception studies continue to be among one of the most researched topics in the field of science education (Lee, Wu, \& Tsai, 2009; Lin, Lin, \& Tsai, 2013).

In this context, the objective of the present research is to understand the conceptions of 4 to 6-year-old children about microorganisms, but does not disregard the context in which the development of these conceptions occurs. Therefore, by trying to comprehend the conceptions manifested by young children in interaction with adults and other children, both in formal (kindergarten) and informal (science museum) spaces, a sociocultural perspective of conception research is assumed (Amin, \& Smith, 2013). We also intend to identify which themes are adequate to develop educational activities in order to broaden the knowledge on microorganisms among children attending kindergartens and preschools. In this paper, we present our findings and considerations arising from such an inquiry.

\section{Theoretical framework}

\section{Young Children and Science Topics}

Children usually begin to show interest in natural phenomena from a very early age (Cavalcanti, 1995; Goulart, 2005). Even so, according to Goulart (2005), we still know very little about how they learn about the natural and social worlds. The author states that "in fact, it is a common belief that very young children cannot learn the concepts peculiar to this type of knowledge. Hence, they are excluded from access to social and scientific knowledge" (Goulart, 2005, p. 25, our translation).

However, Goulart (2007) argues that children know much more than adults normally assume they do. This assertion is supported by research conducted by Dominguez $(2001,2006)$, whose studies with four-year-olds revealed that they formulate hypotheses, make detailed observations, and are able not only to construct meanings about the biological aspects of small animals but also to correctly use the verbal and visual languages to which they had access in the materials made available to them.

Although little research to date has focused on how young children acquire scientific knowledge, numerous authors have reported experiments in which, when conditions were created to give children access to this knowledge, they showed interest in and the ability to learn a great deal (Goulart, \& Gomes, 2000; Castro, 2000; Kawasaki, 2000; Oliveira, 2000; Scarpa, \& Trivelato, 2001; Teixeira, Furtado, \& Wille, 2005; Siry, Ziegler, \& Max, 2012). These findings are in line with the ideas of Lorenzetti and Delizoicov (2001), who claim that the role of scientific literacy is to contribute to children's ability to understand the world around them, which is acquired, among other things, by learning the language of the natural sciences and its meanings. These authors also emphasize that it is essential to use a variety of information sources and languages to promote scientific literacy, stating that "scientific literacy can and should be developed from the beginning of early childhood education, even before the child has learned to read and write" (p. 13, 
our translation). From this standpoint, science education can be a powerful tool for the development of kindergarten children' reading and writing skills, since it helps to assign meanings to words and discourse.

Children are interested in a wide variety of scientific themes. However, upon examining the themes that have been addressed in educational institutions and in research, one finds that they usually involve macroscopic phenomena (Castro, 2000; Goulart, \& Gomes, 2000; Kawasaki, 2000; Oliveira, 2000; Scarpa, \& Trivelato, 2001; Siry, Ziegler, \& Max, 2012; Teixeira, Furtado, \& Wille, 2005). This is probably due to the fact that there is a predominant belief among educators that children are not capable of learning science (Goulart, 2005, 2007; Kirch, 2007; Lima, \& Maués, 2006), which is a difficult and very abstract area even when it involves only "macroscopic issues". Developing activities that focus on microscopic phenomena may therefore be even more daunting for these professionals.

On the other hand, parents and educators often have to introduce children to the microscopic world of everyday life, since a constant concern among adults is to teach them health and hygiene practices, such as washing hands before meals, brushing teeth, wearing clean clothes, bathing, and not putting dirty objects in their mouths (Jones, \& Rua, 2008).

Thus, we must face the challenge of creating favorable conditions to enable children to begin learning about microscopic living beings at a very young age and, as far as possible, to understand the phenomena related to them.

\section{Views about Microorganisms in Different Contexts}

With regard to perceptions about microorganisms and their actions in nature and in the human body, we find different views in the literature. Most studies have revealed that microorganisms are commonly associated with diseases (Byrne, 2011; Byrne, Grace, \& Hanley, 2009; Helman, 1978; Kalish, 1996; Miguel, 2010; Souza, 2009; White, Elsom, \& Prawat, 1980). White, Elsom, and Prawat (1980), who conducted interviews with four-to seven-year-olds to verify their alternative conceptions about death and its causes, found that the action of germs was one of the two most frequently cited reasons.

In contrast, however, Kalish (1996) compared children and adults' alternative conceptions about illnesses and found that children do not associate the occurrence of diseases with the action of germs, while adults attribute the symptoms of fever and the need for medication to the presence of microorganisms. Nevertheless, young children consider all infections contagious, since their everyday experiences indicate that contact with someone suffering from certain symptoms soon thereafter leads to the manifestation of the same symptoms.

Based on interviews with adult patients of the British National Health Service system, Helman (1978) found that even people with limited schooling often associate fever with the action of germs or viruses. According to the concepts revealed in these interviews, these germs are single, i.e., one can only be attacked by one germ at a time, 
and they can be passed on from one person to another, entering through the body's large orifices and causing fever and infections.

In an account of his teaching experience, Miguel (2010) reported that third graders and children in kindergarten with whom he developed health and hygienerelated activities formulated explanatory hypotheses about the action of disease-causing microorganisms. Moreover, they associated these living things with the notion of dirtiness and recognized their presence in some parts of the human body, such as the hands, stomach, and mouth. Several children mentioned the words "bacteria" "viruses", and "bugs".

Souza's work (2009) indicates that even 12- to 16-year-old students commonly associatemicroorganismswith disease or uncleanliness. Moreover, according to the author, few students appear to be aware of the existence of non-pathogenic microorganisms. In questionnaires applied to scientists in the field of microbiology, the same study found that most of them expressed concern in warning the population about the dangers of microorganisms, although many of these professionals also mentioned the beneficial factors of microorganisms for humans and the environment. Other authors, such as Jones and Rua (2008), Simonneaux (2000), Milandri (2004), and Karadon and Sahin (2010), have also found that children and adults associate microorganisms with dirt and diseases. It is interesting to note that these studies reveal not only the notions about microorganisms held by the populations under study but also the considerable interest of researchers themselves in their approach to microbes from a hygienic perspective.

With regard to scientific literacy, it is important for children to recognize the role of microbes in causing disease and for them to learn appropriate practices to protect their health. However, limiting their view of microscopic organisms to the harmful effects that some species cause to human life deprives young children of relevant scientific knowledge, such as the enormous biodiversity among microscopic beings and the biological, medical, and economic importance of some species.

Trivelato (1995) claimed that most seven- to ten-year-olds do not include fungi and bacteria among living beings. According to the author, this represents an obstacle in learning about important biological themes such as mechanisms related to the decomposition of organic matter or to human and animal diseases (Trivelato, 2005). Nonetheless, according to this author, when seven- to ten-year-olds were asked about the decomposition processes, their explanations indicated that their notion is that decomposition involves spontaneous generation, since they ascribe the characteristics observed in decomposing organic materials as inherent to decomposed materials (Trivelato, 2005).

With regard to the decomposition process, Byrne, Grace, and Hanley (2009) found that children associated the action of microorganisms with food spoilage, although no references were made to the biological role of microorganisms in the decomposition of organic matter. These authors conducted an investigation to identify the notions of 7,11 , and 14-year-olds about microorganisms, and reported that children in all these 
age groups had anthropomorphic (human-like characteristics) and anthropocentric (causing some effect on humans) ideas about microscopic beings. They claimed that the two types of notions become less frequent with increasing age, although anthropocentric ideas are more resistant to change.

Inthatstudy, thechildrenidentified dirtyplacesasareascontaining microorganisms, and also attributed the cause of human disease to the action of microbes. These authors also point out the need for more careful educational interventions to expand children's knowledge of microorganisms, their importance, and their role in nature (Byrne, 2011; Byrne, Grace, \& Hanley, 2009).

In another comparative study of children of various ages (7, 11, and 14), Byrne (2011) found that seven-year-olds classified microorganisms as animals or as abstract entities, representing them as small insects and bugs. All the age groups were unanimous in considering microorganisms as living beings that are so tiny that they are invisible to the naked eye. The children made comparisons with familiar objects (pencil tips, dust grains, rice grains) to express the idea of scale. With regard to microorganisms used in the production of foods and medicines, the seven-year-olds did not recognize any relationship. As for terminology, the only word the children in this age group used was "germ".

It is noteworthy that in our review of the literature we found few studies of alternative conceptions of microorganisms that included children younger than seven. Nevertheless, as noted earlier, young children are interested in scientific matters and from an early age hear talk about microorganisms when they are taught to take care of their personal hygiene.

In this regard, several points justify the importance of this research, including: a) the paucity of studies in the field of science education about the microscopic world specifically tailored to four- to six-year-olds; b) the demand for the development of educational strategies that take advantage of children's ability to acquire scientific knowledge; and c) the need for parents to gain a better understanding of microorganisms, given children's evident exposure from a very early age to the narrow standpoint of the harmful effects of microorganisms to humans. It is therefore necessary to face the challenge of creating conditions that enable young children to begin the process of learning about microscopic living beings and, as far as possible, understanding the phenomena related to them.

As pointed out previously, the objective of this work was to investigate how fourto six-year-olds think about the aforementioned matters, what associations children make when they talk about the subject, and whether they are able to recognize the biodiversity and biological importance of microorganisms. Therefore, the aim of this study was to help fill this gap related to an absence of literature about young children's ideas about microorganisms. Besides, we aimed at identifying which approaches can be adopted to elaborate educational activities on microorganisms for children attending kindergartens and preschools. 


\section{Methodology of Research}

\section{Contexts in which the data were collected}

To carry out this research, data were collected from 2008 to 2011 in two very different contexts: a science museum and a kindergarten. The data collected in the Museum allowed us to verify if the four- to six-year-olds were able to think about microorganisms, and how they interacted and understood the materials presented for them in an informal environment. On the other hand, the collection of data in the kindergarten allowed us to follow the development of children's ideas for a longer period in a school context, which gave us a better comprehension on how children constructed their thoughts about microorganisms.

Individual interviews were held with 22 children accompanied by their relatives at the Museum of Microbiology, Butantan Institute (São Paulo, Brazil), where they were invited to enter a space reserved for them upon their arrival. After explanation the aims of the study, informed consent was obtained from the parents or responsible person of all children included in the study. The sociodemographic data collected at the museum showed a highly heterogeneous public, since the characteristics of the families differ significantly in terms of the parents' level of education, their habit of visiting museums, interest in scientific topics, previous knowledge of scientific subjects, habit of discussing scientific issues with the child, etc. Moreover, this group comprised as many children attending kindergartens or preschools as children who had never attended any institution. It should also be kept in mind that contact with each visitor took place only once.

The other place from which data were collected was a kindergarten belonging to a university located in Sao Paulo city (São Paulo, Brazil), designated here with the fictitious name EEI. This study involved a group of 13 five-year-olds from EEI over a period of approximately one month, during which several activities proposed specifically for this research were carried out. The parents of the children, when entering their children in this kindergarten, agreed to their participation in scientific studies. The sociodemographic data collected at the EEI showed a heterogeneous group in terms of social and economic aspects, but with a unique characteristic: all children have parents who are connected to the university, whether as students, employees, or lectures.

The different characteristics of each context had an influence not only on the way the data were collected but also in the type of information that was obtained from these data, as will be seen later. Collection was adapted to the routines and characteristics of each institution: at the day care the children participated in four workshops on different days with stories and drawings as mediation instruments, whereas at the museum they participated on only one visit, which was focused on manipulating images and drawings. These differences may interfere with the type of data produced. On the one hand, the fact that there were sequential workshops enables us to track the ideas expressed by a child as to their changes throughout the educational action; on the other hand, the 
data are related to early, immediate manifestations, expressed by the child in a single encounter. It should be noted that the main reason these two educational environments (kindergarten and museum) were chosen was not to compare them but to broaden the methodological possibilities and the variety of subjects involved.

\section{Collection of data at the Microbiology Museum}

At the Museum, the children's perceptions about microorganisms were investigated based on an analysis of 22 audio-visually recorded interviews and of the children's drawings and plasticine sculptures. It must be highlighted that the children could choose between representing their ideas with drawings or play-doh. However, those who chose play-doh represented serpents rather than microorganisms for the most part, especially because of the proximity of the Microbiology Museum to the Biological Museum of the Butantan Institute. This institution is nicknamed the "snake museum" by the population. For this reason, only the drawings were considered.

When groups of visitors that included four- to six-year-olds arrived at the museum, they were invited to come into a designated space containing a variety of materials designed to encourage them to talk and to make graphic productions about microorganisms (Figure 1). The work team comprised three people: one in charge of filming, an interviewer (one of the authors), and a person responsible for receiving the visitor, filling out the form, and obtaining the authorization of the parents or adult responsible for the child. A semi-structured interview script was prepared and the children were invited to answer questions aimed at identifying their notions about microorganisms, i.e., their definitions and descriptions of these living beings, where they believe microorganisms occur, and their perceptions about their shape, size, and functions.

The interview was carried out after the children visited the space that was prepared for them. Some questions referred to what the children could observe, while others inquired about the children's explanations for the actions of the microorganisms on the environment and the body. There were questions about the locations of the microorganisms in their environment in nature, domestic settings, and the human body. Finally, there were questions on the characteristics attributed to the microorganisms by the children. Such features were verbally elicited and were also represented in the drawings.

We also sought to understand how children create hypotheses about technical mechanisms to visualize microorganisms based on observations about the handling of different optical magnifying instruments (fixed and hand-held magnifying glasses, a microscope connected to a TV set, and Eyeclops ${ }^{\oplus}$ - a toy that, when connected to a TV, magnifies the image of the object being targeted). The children were shown representative images of environments (such as different rooms in a house and natural environments) and of the human body, and were asked to identify the places where microorganisms occur. 
After being interviewed, the children were encouraged to draw pictures or make sculptures on the theme "microorganisms". The interviews were recorded audio-visually and later transcribed.

\begin{tabular}{|c|c|c|c|c|}
\hline Activities & $\begin{array}{l}\text { Purpose of the } \\
\text { activities }\end{array}$ & $\begin{array}{l}\text { Collected } \\
\text { data }\end{array}$ & Analyzed data & Results \\
\hline Eye Clops & $\begin{array}{l}\text { Verify if the } \\
\text { children were } \\
\text { able to realize the } \\
\text { magnification effect } \\
\text { of the equipment } \\
\text { and if they could } \\
\text { manipulate the } \\
\text { apparatus without } \\
\text { any help. }\end{array}$ & $\begin{array}{l}\text { Videotaping, } \\
\text { observation } \\
\text { and } \\
\text { description of } \\
\text { the behavior } \\
\text { of the children } \\
\text { during the } \\
\text { activity. }\end{array}$ & $\begin{array}{l}\text { Analysis of the } \\
\text { videotapes and } \\
\text { child behavior } \\
\text { register. }\end{array}$ & $\begin{array}{l}\text { The children did not } \\
\text { demonstrate ability } \\
\text { to manipulate the Eye } \\
\text { Clops. } \\
\text { The majority of } \\
\text { children did not } \\
\text { realize that the image } \\
\text { generated by the } \\
\text { equipment was a } \\
\text { magnification. }\end{array}$ \\
\hline $\begin{array}{l}\text { Magnifying } \\
\text { glasses }\end{array}$ & $\begin{array}{l}\text { Verify if the } \\
\text { children were } \\
\text { able to use the } \\
\text { magnifying } \\
\text { glasses and if they } \\
\text { understand that } \\
\text { these instruments } \\
\text { can magnify the } \\
\text { objects. }\end{array}$ & $\begin{array}{l}\text { Videotaping, } \\
\text { observation } \\
\text { and } \\
\text { description of } \\
\text { the behavior } \\
\text { of the children } \\
\text { during the } \\
\text { activity. }\end{array}$ & $\begin{array}{l}\text { Analysis of the } \\
\text { videotapes and } \\
\text { transcription } \\
\text { of the } \\
\text { conversations. }\end{array}$ & $\begin{array}{l}\text { The children did not } \\
\text { manifest any interest by } \\
\text { the magnifying glasses } \\
\text { and the majority did } \\
\text { not demonstrate ability } \\
\text { to use them. } \\
\text { However, after } \\
\text { receiving some } \\
\text { instructions, they } \\
\text { quickly learned } \\
\text { how to use the } \\
\text { magnifying glasses and } \\
\text { demonstrated pleasure } \\
\text { in doing the activity. }\end{array}$ \\
\hline $\begin{array}{l}\text { Three- } \\
\text { dimensional } \\
\text { models of } \\
\text { microorganisms } \\
\text { (bacteria, } \\
\text { virus, fungi } \\
\text { and protozoa) } \\
\text { made of resin or } \\
\text { plush }\end{array}$ & $\begin{array}{l}\text { Investigate if the } \\
\text { children showed } \\
\text { some preference for } \\
\text { manipulating the } \\
\text { three- dimensional } \\
\text { objects or for } \\
\text { observing images of } \\
\text { microorganisms. }\end{array}$ & $\begin{array}{l}\text { Videotaping, } \\
\text { observation } \\
\text { and } \\
\text { description of } \\
\text { the behavior } \\
\text { of the children } \\
\text { during the } \\
\text { activity. }\end{array}$ & $\begin{array}{l}\text { Analysis of the } \\
\text { videotapes and } \\
\text { child behavior } \\
\text { register. } \\
\text { Identification } \\
\text { of the child } \\
\text { preferred } \\
\text { microorganism } \\
\text { representations. }\end{array}$ & $\begin{array}{l}\text { There was no } \\
\text { preference for 3D } \\
\text { objects in relation to } \\
\text { the printed images. } \\
\text { When compared 3D } \\
\text { objects of plush or } \\
\text { resin, the children } \\
\text { declare that the ones } \\
\text { made of plush were } \\
\text { more similar to the } \\
\text { actual microorganisms } \\
\text { than the resin models. }\end{array}$ \\
\hline
\end{tabular}

Figure 1. Activities carried out with the children at the Museum of Microbiology 


\begin{tabular}{|c|c|c|c|c|}
\hline Activities & $\begin{array}{l}\text { Purpose of the } \\
\text { activities }\end{array}$ & Collected data & Analyzed data & Results \\
\hline $\begin{array}{l}\text { Different } \\
\text { styles of } \\
\text { microorganisms } \\
\text { images } \\
\text { (photographs, } \\
\text { anthropo- } \\
\text { morphized } \\
\text { imagens, } \\
\text { scientific } \\
\text { drawings) }\end{array}$ & $\begin{array}{l}\text { Determine which } \\
\text { images the children } \\
\text { identify with } \\
\text { microorganisms. } \\
\text { Verify if the } \\
\text { children had } \\
\text { preference for more } \\
\text { realistic images or } \\
\text { for the anthropo- } \\
\text { morphized ones. }\end{array}$ & $\begin{array}{l}\text { Videotaping, } \\
\text { observation and } \\
\text { description of } \\
\text { the behavior } \\
\text { of the children } \\
\text { during the } \\
\text { activity. } \\
\text { Interviewing } \\
\text { the children } \\
\text { about which } \\
\text { images they } \\
\text { considered } \\
\text { more realistic. }\end{array}$ & $\begin{array}{l}\text { Analysis of the } \\
\text { indications } \\
\text { made by the } \\
\text { children about } \\
\text { the images they } \\
\text { consider more } \\
\text { similar to the } \\
\text { microbes. }\end{array}$ & $\begin{array}{l}\text { The children } \\
\text { considered the } \\
\text { photographs } \\
\text { more similar to } \\
\text { microorganisms } \\
\text { than the anthropo- } \\
\text { morphized images. } \\
\text { There was no precise } \\
\text { indication of which } \\
\text { images the children } \\
\text { considered more } \\
\text { realistic. } \\
\text { It seems that there was } \\
\text { no preference between } \\
\text { anthropo-morphized } \\
\text { or scientific images. }\end{array}$ \\
\hline $\begin{array}{l}\text { Interview after } \\
\text { the visit }\end{array}$ & $\begin{array}{l}\text { Identify which } \\
\text { apparatus were the } \\
\text { most adequate. } \\
\text { Determine the } \\
\text { ideas that children } \\
\text { have about the } \\
\text { microorganisms. }\end{array}$ & $\begin{array}{l}\text { Transcription } \\
\text { of the } \\
\text { interviews. }\end{array}$ & $\begin{array}{l}\text { Analysis } \\
\text { of the } \\
\text { interviews. }\end{array}$ & $\begin{array}{l}\text { There was no } \\
\text { preference between } \\
\text { manipulation of 3D } \\
\text { objects or observation } \\
\text { of printed images. } \\
\text { The children } \\
\text { spontaneously } \\
\text { mentioned terms } \\
\text { associated with } \\
\text { microorganisms. } \\
\text { They were able } \\
\text { to approach the } \\
\text { acknowledgment on } \\
\text { microorganisms. }\end{array}$ \\
\hline
\end{tabular}

Figure 1. Activities carried out with the children at the Museum of Microbiology (continuation)

\section{Collection of data in the kindergarten}

The activities in the kindergarten were carried out with a group of 13 five-year-old children and divided into four sessions (Figure 2). The interventions aimed at leading the children to explain - verbally or through drawings - their ideas about scale, habitat, and diversity of microorganisms. A list of questions to be answered during the interactions with the researcher was prepared beforehand. According to the education coordinator, a few months before these data were collected, the theme "microbes" had been studied intensively at the kindergarten to stimulate the development of healthy hygiene habits. 
The activities were developed in four days (Figure 2). Initially, it was proposed a conversation circle in which the children were encouraged to talk about their hygiene habits. In the second day, we presented them several pictures: 1) human body, 2) rooms in an ordinary house, and 3) photos of places in the kindergarten familiar to the children (park, vegetable garden and compost heap). The children were asked to point out, in small groups, the places where there were microbes. Drawings of microbes or of places containing microbes were produced by the children and collected for analysis. Already on the third day, we read an informative book and asked a request for a drawing. In the fourth day, a scientific text entitled "Sorvete Saúde" [Healthy Ice Cream] (Abreu, 2006), concerning the use of microorganisms for the production of some ice creams, was also read.

\begin{tabular}{|c|c|c|c|c|}
\hline Session & Activities & $\begin{array}{l}\text { Purpose of the } \\
\text { activities }\end{array}$ & Analyzed data & Results \\
\hline Day 1 & $\begin{array}{l}\text { A conversation } \\
\text { circle about } \\
\text { hygiene habits. }\end{array}$ & $\begin{array}{l}\text { Check if the children } \\
\text { use words related } \\
\text { to the theme } \\
\text { "microorganism" } \\
\text { spontaneously. }\end{array}$ & $\begin{array}{l}\text { Analysis of the } \\
\text { transcription of the } \\
\text { conversations. }\end{array}$ & $\begin{array}{l}\text { We verified that } \\
\text { children use words } \\
\text { as virus and bacteria } \\
\text { spontaneously. }\end{array}$ \\
\hline Day 2 & $\begin{array}{l}\text { Presentation } \\
\text { of pictures: } \\
\text { Collection of } \\
\text { drawings. }\end{array}$ & $\begin{array}{l}\text { Determine what } \\
\text { the children know } \\
\text { about places where } \\
\text { microorganisms are } \\
\text { present. }\end{array}$ & $\begin{array}{l}\text { Analysis of drawings } \\
\text { and the children } \\
\text { statements. }\end{array}$ & $\begin{array}{l}\text { The analysis of the } \\
\text { transcript indicated } \\
\text { indicate that } \\
\text { children associate } \\
\text { the presence of } \\
\text { microorganisms } \\
\text { with places they } \\
\text { consider dirty. }\end{array}$ \\
\hline Day 3 & $\begin{array}{l}\text { Reading of an } \\
\text { informative } \\
\text { book and } \\
\text { request for a } \\
\text { drawing. }\end{array}$ & $\begin{array}{l}\text { Expand the } \\
\text { children's repertoire } \\
\text { of ideas about } \\
\text { microorganisms. } \\
\text { Ascertain the } \\
\text { conceptions revealed } \\
\text { by their drawings. }\end{array}$ & $\begin{array}{l}\text { Analysis of } \\
\text { conversations transcript } \\
\text { during the reading of } \\
\text { the book } \\
\text { Analysis of drawings } \\
\text { and explanation of each } \\
\text { child about his/her } \\
\text { drawing. }\end{array}$ & $\begin{array}{l}\text { The children } \\
\text { consider } \\
\text { microorganisms } \\
\text { morphologically } \\
\text { similar to insects, } \\
\text { and they use various } \\
\text { scientific words } \\
\text { appropriately. }\end{array}$ \\
\hline Day 4 & $\begin{array}{l}\text { Reading of a } \\
\text { scientific text. }\end{array}$ & $\begin{array}{l}\text { Give the children } \\
\text { information about } \\
\text { the existence of } \\
\text { microorganisms that } \\
\text { have beneficial effects } \\
\text { on human health. }\end{array}$ & $\begin{array}{l}\text { Analysis of the } \\
\text { discussion transcript. } \\
\text { Analysis of the } \\
\text { explanation of each } \\
\text { child about his/her } \\
\text { drawing. }\end{array}$ & $\begin{array}{l}\text { The children } \\
\text { accepted the idea } \\
\text { about beneficial } \\
\text { effects of microbes } \\
\text { on human health, } \\
\text { attributing positive } \\
\text { characteristics to this } \\
\text { type of microbe. }\end{array}$ \\
\hline
\end{tabular}

Figure 2. Activities carried out with the children at the EEI 


\section{Data Analysis}

The data analysis was based on the audiovisual recordings, field notes, and the drawings produced by the children. The data were analyzed qualitatively, since the purpose of this research was to identify the alternative conceptions four- to six-year-old children have about microorganisms. In both cases (museum and kindergarten), the data analysis involved transcription of interviews and visit recordings, followed by qualitative content analysis, according Bardin (2011). After the interpretation of transcriptions and images, the following categories emerged: existence of microorganisms, morphological aspects, habits of microorganisms, places where they can be found, interactions with human being, role of microorganism in biological world. All transcriptions were analyzed again by at least two researchers, which helped us to validate the categories and the use of them. Also, we validated our interview script using a pilot script, applied to volunteers' families at the Museum. It is important to note that all responsible adults signed consent terms (TCLE).

\section{Results}

After completing the initial data collection at the two institutions, we sought to identify, from the children's spoken exchanges and drawings, what conceptions they revealed about microorganisms. We have chosen to insert the children's dialogues here because we want to give voice to them, which we achieve by reporting their representative speeches. Fictional names are used here to protect the identity of the children who participated in this research.

We found that most of the children at both the museum and the kindergarten not only understand the existence of microorganisms but also that, when prompted to talk about them, spontaneously use words associated with the subject, indicating that they have already begun to learn the meanings of specific terms. For instance, in the first conversation circle at the kindergarten, when personal hygiene practices were discussed, the children made the following statements:

Caroline: "Microbes reach the tooth and make a little hole that grows, grows, grows and this little hole is what we call caries".

Daniel: "I know what a virus is, it's when it gives you a disease, right, César?"

The interviews at the museum also revealed that children use microorganismrelated vocabulary correctly. Two examples that indicate this appropriation are given below.

Interviewer: "Because it's dirty. And what's in the dirt?"

Clara: "Bacteria"

Julio: "Microbes" 
The children's drawings revealed that representations of microorganisms morphologically resembling insects, with wings, mouth, eyes, antennae, and legs, are very common.

The drawings below clearly show the presence of legs (Figures 3 and 4).

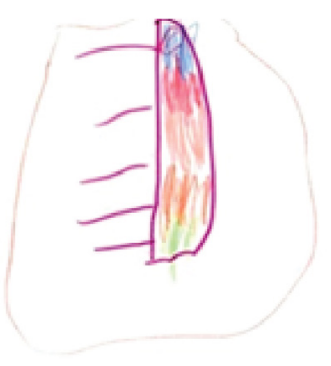

Figure 3. Drawing of a microorganism with legs, produced by a child participating in this research

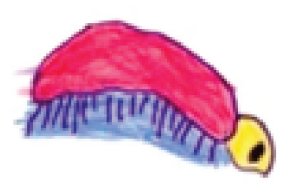

Figure 4. Drawing of a microorganism with legs and head, produced by a participant of this research

Figures 4 and 5 indicate that the author of the drawing imagines microbes that have legs, eyes located at one extremity of the body, and in the case of Figure 5, a head separate from the body.

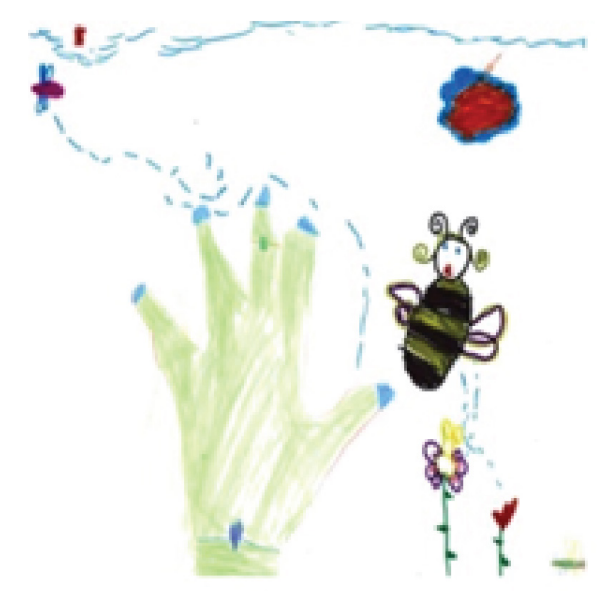

Figure 5. Microbe depicted in flight (dotted lines starting from the child's hand) in a drawing produced by a child participating in this study

The children mentioned other morphological aspects:

Interviewer: "Is a microbe the same or different from a bacterium?" 
Patrícia: "I don't think so... A microbe is green and a bacterium is pink..."

During one of the interviews at the museum, when the researcher asked the child to explain her drawing, we found the presence of antennae in the picture of a microorganism.

With regard to the habits of microorganisms, the examples below reveal interesting alternative conceptions about microbes that are aquatic, that fly, or are located on bees.

Maria: "There are bacteria that live in water..." microbe...”

Bianca: "Yeah. I'm going to draw a bee because it was going to a flower, and it had a

When naming the elements of the drawing, the girl mentioned the words "microbe", "bee", and "flowers". The microbe has wings and was represented during its "flight", which once again indicates a similarity not only in the shapes of microbes and insects but also in their "behavior".

On another occasion in the kindergarten, when the researcher encouraged the children to think about the diversity of microorganisms, an idea emerged about how these living beings reproduce:

Interviewer: "Are you drawing a microbe, Lucas?"

Lucas: "It's a little egg of a microbe."

As for the places where these living things can be found, the data from both the museum and the kindergarten indicate that children associate the presence of microorganisms with places they consider dirty.

The following transcript refers to an occasion when the researcher showed photos of the inside of a house to two children visiting the museum.

Interviewer: "What about here in the kitchen - do you think there are any [microbes]?"

Camila: "There are where it isn't cleaned."

Camila: "Poop."

Camila: "And in the garbage can."

Just as with the museum, when presented with pictures, the places the kindergarteners pointed out most frequently were the garbage can and the floor. It was interesting to note that when presented with pictures of kitchens, the children took longer to point out places containing microbes than when they looked at pictures of a bathroom. The following excerpt illustrates the association they made between the location of microorganisms and the idea of dirtiness:

Interviewer: "Where do you think there are microbes?"

Tiago: "Ah, in the hospital, right? On the floor of the hospital" 
Interviewer: "Why on the floor of the hospital?"

Tiago: "Because there's no dirt there?And doesn't dirt have microbes?"

In addition to dirty places, it was also evident that the kindergarten children, unlike the children at the museum, understood the fact that there are microorganisms in various places they go to regularly. This group, in addition to photographs of homes, was also shown photographs of places inside the kindergarten itself that they use daily:

Interviewer: "What about the sandbox - are there microbes here?"

Bianca: "Yeah"

Interviewer: "Where else?"

Bianca: "In the tree"

Interviewer: "And here in the compost heap, do you think there are microbes? Or not?"

Bianca: "In the garbage"

Regina: "I think there are [microbes] in the earth..."

Children recognize that there are also microorganisms in the human body. While the researcher was showing them images of the human body, the parts of the body most frequently identified as carriers of microorganisms were "hands" "feet", and "mouth". However, there were associations with various parts of the body, as can be seen in the transcribed dialogue below, which took place at the kindergarten:

Evandro: "In the mouth"

Douglas: "Here in the foot"

José: "I think there are [microbes]... In the body..." (pointing at the arm)

Francisco: "I know, in the eye."

Douglas: "Also in the nose... On the finger..."

The results obtained during the interviews held at the museum are very similar to those found in the kindergarten.

As we showed previously, in addition to recognizing the existence of microorganisms in various parts of the human body, many children associated them with diseases. The children attributed the formation of dental caries to the action of bacteria and made associations between the presence of microorganisms and the need for oral and personal hygiene habits.

Although the association between microorganisms and negative effects predominates, some children recognize the existence of some microorganisms that are 
not harmful, as can be seen in the following excerpt from one of the interviews held at the museum:

Antônio: "There are good bacteria, too"

In another interview at the museum the researcher asked:

Interviewer: But are microbes in clean places or only in dirty places?

João: No. There are microbes in clean places, too.

João: They can be good. It depends on the microbe.

On another occasion, when the researcher at the kindergarten read an article that mentioned the use of microorganisms for the production of ice cream, the children accepted the idea, attributing positive characteristics to this type of microbe.

Note that one of the interviewed boys (Caio, 5) demonstrated that he understood that it is possible for microorganisms to perform a variety of actions in different living beings. The boy drew a picture of a microbe on a dinosaur and claimed it was the same as the one found in dirt (Figure 6). The dialogue between this child and the researcher demonstrates that it is possible for a child of that age to understand that microorganisms can cause different effects depending on the context in which they appear.

Interviewer: "What does this little bug do here on the dinosaur?"

Caio: "Nothing!"

Interviewer: "Nothing? And if it's on us?"

Caio: "It gives you fever, tummy ache..."

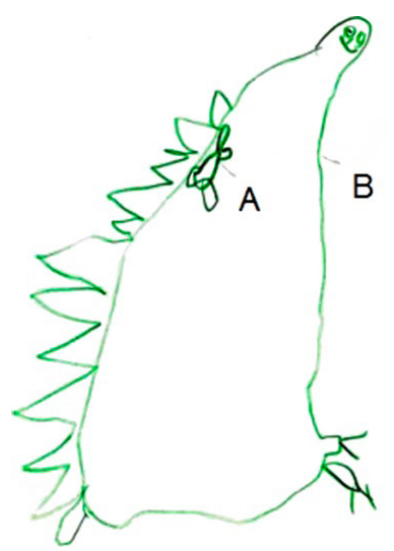

Figure 6. Drawing produced by Caio during an interview: A) microbe; B) dinosaur

The idea of scale appeared in the spoken exchanges of children when they mentioned the "tiny" size of microorganisms.

At the kindergarten, the question of size arose in different situations, as indicated 
by the following examples:

Ana: [...] "really very tiny" (Referring to the microbe that causes dental caries.)

The girl then makes a little dot with a pen she is holding and says:

Ana: "Look, it's smaller than that!"

Interviewer: "Have you ever seen a microbe in the sand in the yard?"

Igor: "No... They're too tiny"

Like Ana's comparison of the dot made with the tip of her pen and the size of a microorganism, the example that follows, taken from an interview held at the museum, shows how this comparison between known referents can help children think about the question of scale and express the idea of "very small".

Interviewer: "Let me ask you a question. Is a bee bigger or smaller than a bacterium?"

Pedro: "Bigger. Much bigger. Because one can't even see a bacterium. It's microscopic. You can't see it. It's so tiny that you can't see it"

Among the visitors to the museum, another aspect worth mentioning concerning this topic is the finding that the children's understanding of the magnification provided by the instruments on display varied greatly. While some demonstrated that they understood the use of instruments to view magnified images of microorganisms, others appeared not to attribute a new way of viewing these living beings to the instruments.

Bruna and Ligia's comments regarding the protozoa viewed under the microscope connected to the TV screen are good examples of this situation:

Interviewer: "Do you think those little bugs on the television are large or small?"

Bruna: "Small"

Interviewer: "Do you think they're small? Do you think they're the size you see on the TV or are they smaller?"

Bruna: "The size that appears [on the TV]"

Interviewer: "What about you? What do you think, Lígia?"

Lígia: "I think they're smaller"

Interviewer: "Could it be that on the TV they are being magnified, like with this instrument?" (referring to an Eyeclops ${ }^{\circ}$ )

Bruna: "I don't know" 


\section{Discussion}

To enrich the discussion, the results from the kindergarten and the microbiology museum are discussed jointly, considering that the data collected at the two sites showed convergences and divergences. As mentioned earlier, these were found not only in the composition of the group but also in the way the data were collected. While all the children at the kindergarten had already engaged in educational activities concerning microorganisms, only a few of the visitors at the museum had. Moreover, the sessions with the kindergarten children were consecutive, enabling a closer relationship between the research subjects, greater interaction within the group, and a more vertical understanding of the children's thoughts about microorganisms. In contrast, although the data from the museum were collected in single events (only one brief meeting with each child), they involved a larger number of interviewees, allowing for a more horizontal understanding with a greater representativeness of subjects.

Having highlighted the methodological variations, we will now present some thoughts about how children think about microorganisms.

It is noteworthy that the children not only employed words related to the subject but did so in context, indicating not only that they know the words themselves but that they understand their meanings. Similar data was not found in earlier studies in the literature (Byrne, 2011). It is also interesting to note from the above excerpts that although the way in which the data were collected at the two institutions differed considerably, in both situations the children showed not only that they are familiar with the subject of "microorganisms" but also that they know how to use terms related to this subject context-consistently.

With regard to morphological diversity, it was evident, both in their drawings and in their verbal exchanges, that children attribute a variety of characteristics to microorganisms, indicating that there are differences between them. At the kindergarten, more references were made to habitats occupied by microorganisms, while at the museum, the association between microorganisms and dirty places predominated.

The interviewed children made a clear association between microorganisms and dirt. The association between microorganisms and negative aspects such as dirt and disease demonstrated at the two institutions is consistent with the findings of several other studies (Byrne, 2011; Byrne, Grace, \& Hanley, 2009; Helman, 1978; Kalish, 1996; Miguel, 2010; Souza, 2009; White, Elsom, \& Prawat, 1980). This excerpt of conversation is interesting because the children believe there are microorganisms in various places where they usually play: sand, trees, the earth, and compost heaps. It is interesting to note that although the findings at the museum and kindergarten regarding places where microorganisms are found were similar, the kindergarten children attribute the presence of microbes to a far greater variety of places than those at the museum.

As mentioned earlier, the theme "microorganisms" was addressed in the kindergarten several months before this study began, which probably explains the apparent difference in the results obtained at the museum (fewer associations) and 
the kindergarten (a wider range of associations). This finding allows us to state that investments in educational interventions for the development of this theme with small children can be very fruitful, since the results indicate that, given the opportunity, they are able to acquire knowledge about this subject.

We found that the children recognized microorganisms predominantly as pathogenic agents. As Byrne, Grace, and Hanley (2009), Miguel (2010), and Byrne (2011) point out, the associations made between humans and microorganisms are usually restricted to their negative aspects, since children either mention diseases caused by microorganisms or state that microorganisms are located in specific parts of the body considered dirtier, such as feet, hands, or nose. However, in this investigation, although the children did not spontaneously mention the actions of microorganisms that are beneficial to humans, they accept the possibility that positive characteristics can be attributed to these living beings like Antonio e João.

The data indicate that most children understand the existence of organisms so tiny that they are invisible to the naked eye. Some of them mention this explicitly, indicating that microbes are "very tiny". Others are even more specific, making comparisons of size such as "smaller than a louse" or "smaller than this dot", which indicates they already have some notions of scale. These findings coincide with those of Byrne, Grace, and Hanley (2009), and Byrne (2011).

\section{Conclusions and Implications}

Based on the data analyzed here, we can conclude that children not only use the specific vocabulary related to bacteria, virus and microbes, but also are able to think about several aspects of the microorganisms. Thus, children relate microorganisms mainly to dirty places, but they also admit there are microbes in domestic environments, in human body, as point out already by Miguel (2010), and in natural environments. Children are able to think about scale and admit the existence of live beings that cannot be seen with naked eyes. Although in a limited way, the data revealed that children can recognize there could be inoffensive or even beneficial microorganisms.

Our findings lead us to conclude that it is possible and desirable to invest in educational activities related to microorganisms with four- to six-year-olds, since the subjects of this research showed a keen interest in discussions on the subject, understanding various aspects of microorganisms and demonstrating their ability to think about the subject even without making direct observations. Moreover, contrary to what occurred in Byrne's research (2011), in which the only word the group of sevenyear-olds used was "germ", in our study we found that the children are able to learn various specific scientific terms (bacteria, virus, viruses, and microbe). This indicates that when given access to knowledge and practices concerning microorganisms, children are able to assign meanings to the representative terms of scientific culture. Thus, we identified some of the main points that can be addressed in educational activities with young children, i.e., biodiversity, scale, biological function, and relationships with humans and 
food.

With regard to biodiversity, children's knowledge can be expanded by showing them images of different microorganisms (so that they perceive that there are variations in shape and size). Furthermore, it is important for them to have access to more comprehensive information about forms of life and habitats, so that they grasp the magnitude of the variety of microscopic living beings. This will enable them to recognize the existence of microorganisms that are harmless or even beneficial to humans, and in particular, render their concepts about the subject less anthropocentric.

The question of scale can also be addressed at an early age, since the children revealed not only that they can understand it but can also make comparisons of size spontaneously. This finding is corroborated by the work of Prokop, Fančovičová and Krajčovičová (2016) that point out that children who often get sick draw microorganisms in much smaller size than others, indicating a scale idea. Although small children have no difficulty in using their imagination to talk about the microscopic world, they rarely have access to magnifying instruments. Thus, enabling them to observe slides with microorganisms under the microscope or allowing them to use magnifying glasses to magnify small objects may be an interesting way to introduce them to scientific culture and its way of knowledge building.

As has been pointed out by other researchers (Byrne, 2011; Byrne, Grace, \& Hanley, 2009; Helman, 1978; Kalish, 1996; Miguel, 2010; Souza, 2009; White, Elsom, \& Prawat, 1980; Prokop, Fančovičová, \& Krajčovičová, 2016), we found that the children recognized microorganisms predominantly as pathogenic agents. However, the data from the kindergarten indicated that the children cited the presence of microorganisms in compost and in various other environments, and accepted the information that some bacteria are used in the production of ice cream.

With regard to the places where microorganisms can be found, Prokop, Fančovičová and Krajčovičová (2016) noted that children indicate their presence in the human body, as in the intestinal cavity, oral cavity, hands, lungs and eyes. This finding coincides with ours, which points to the possibility of discussing the subject of food.

Although the theme of food was not addressed by the children, this is considered a very important theme for the development of healthy habits and to enable them to recognize the role of microorganisms in food technology. It is possible that by knowing how bread, yogurt and cheese are produced, children will more often make other associations besides those relating to pathologies.

The aforementioned thematic lines could be addressed both at institutions of formal education such as kindergartens and preschools and at institutions of non-formal education, e.g., science museums. This, of course, depends on the particulars of each institution. While visitors to science museums spend little time there and return only infrequently, children attend kindergartens and preschools daily.

Therefore, we believe that the organization of exhibitions and other educational actions in museum spaces should be designed so that the selected thematic lines and 
objects are easily recognizable by the visiting public. Presenting the same theme by means of different apparatuses in an exhibition, for instance, may stimulate the establishment of relationships between scientific knowledge and different forms of representing it. The use of varied objects that are representative both of the sciences (such as magnifying glasses, microscopes and three-dimensional models of microorganisms) and of day-today situations (such as representations of the human body or the use of microorganisms in food production) can promote a perception that goes beyond pathogenicity. Moreover, it is important that information be demonstrable and understandable without the need for verbal and reading competencies. Apparatuses made available ergonomically to children can be organized to promote the child's autonomous use and rapid interpretation by the adults in charge. Supporting materials for young visitors, such as guides and audiovisuals, may offer possibilities for new approaches to the theme of microbiology after a visit to the museum.

As for institutions of formal education, it is important first that teacher training actions be adopted to qualify teachers for this work, since most of them lack training in the fields of science or biology. Furthermore, it is essential for children to have access to diverse informative materials to enable them to express themselves through different languages (drawings, paintings, games, songs, conversations circles) so that they can achieve such knowledge.

\section{References}

Abreu, C. (2006). Sorvete Saúde. Ciência Hoje das Crianças, 173, 31-33.

Amin, T., \& Smith, C. (2013). Student Conceptions and Conceptual Change: Three Overlapping Phases of Research. In N. Lederman \& S. K. Abell (Eds.), Handbook of Research in Science Education, Vol. II. New York: Routledge.

Bardin, L. (2011). Análise de Conteúdo. Lisboa: Edições 70.

Byrne, J., Grace, M., \& Hanley, P. (2009). Children's anthropomorphic and anthropocentric ideas about micro-organisms. Journal of biological education, 44(1), 37-43.

Byrne, J. (2011). Models of micro-organisms: children's knowledge and understanding of micro-organisms from 7 to 14 years old. International Journal of Science Education, 33(14), 1927-1961.

Castro, S. T. (2000). O museu e o ensino de ciências na educação infantil: experiências do museu oceanográfico - Instituto Oceanográfico da Universidade de São Paulo. In Anais VII Encontro Perspectivas do Ensino de Biologia (pp. 670-672.), São Paulo: FEUSP. Cavalcanti, Z. (1995). Trabalhando com história e ciências na pré-escola. Porto Alegre, Rio Grande do Sul: Artes Médicas. 
Dominguez, C. R. C. (2001). Rodas de ciências na Educação Infantil: um aprendizado lúdico e prazeroso (Dissertação de Mestrado). Faculdade de Educação, Universidade de São Paulo, São Paulo, Brasil.

Dominguez, C. R. C. (2006). Desenhos, palavras e borboletas na Educação Infantil: brincadeiras com as ideias no processo de significação sobre os seres vivos (Tese de Doutorado). Faculdade de Educação, Universidade de São Paulo, São Paulo, Brasil.

Duit, R. (2009). Students' and Teachers' Conceptions and Science Education. Bibliography - STCSE. Retrieved from http://archiv.ipn.uni-kiel.de/stcse/

Goulart, M. I. M. (2005). Conhecimento do mundo natural e social: desafios para a educação infantil. Revista Criança, 38, 25-29. Retrieved from http://portal.mec.gov.br/ seb/arquivos/pdf/rev_crian_39.pdf.

Goulart, M. I. M. (2007). Early childhood science education: what is the challenge? Cultural Studies of Science Education, 2, 835-840.

Goulart, M. I .M., \& Gomes, M. F. C. A. (2000). A construção de conceitos em ciências naturais na interação em sala de aula. In Conferência de Pesquisa Sócio-cultural. Retrieved from http://www.fae.unicamp.br/ br2000/trabs/1020.doc.

Helman, C. G. (1978). Feed a cold, starve a fever - folk models of infection in an english suburban community, and their relation to medical treatment. Culture, medicine and psychiatry, 2, 107-137.

Jones, M. G. \& Rua, M. J. (2018). Conceptual representations of flu and microbial illness held by students, teachers, and medical professionals. School Science and Mathematics, 108(6), 263-278.

Kalish, C. (1996). Causes and symptoms in preschoolers' conceptions of illness. Child Development, 67, 1647-1670.

Karadon, H. D., \& Sahin, N. (2010). Primary school students' basic knowledge, opinions and risk perceptions about microorganisms. Procedia Social and Behavioral Sciences 2, 4398-4401.

Kawasaki, C. S. (2000). Calendário biológico: uma experiência pedagógica desenvolvida na Creche Carochinha do campus da USP de Ribeirão Preto. In VII Anais Encontro Perspectivas do Ensino de Biologia (pp. 751-754), São Paulo: FEUSP.

Kirch, S. A. (2007). Re/Production of science process skills and a scientific ethos in an early childhood classroom. Cultural Studies of Science Education, 2(4), 785-845.

Lee, M. H., Wu, Y. T. \& Tsai, C. C. (2009). Research Trends in Science Education from 2003 to 2007: A content analysis of publication in selected journals. International Journal of Science Education, 31(15), 1999-2020. 
Lin, T. C., Lin, T. J., \& Tsai, C. C. (2013). Research Trends in Science Education from 2003 to 2007: A content analysis of publications in selected journals. International Journal of Science Education, 36(8), 1346-1372.

Lima, M. E. C. C., \& Maués, E. (2006). Uma releitura do papel da professora das séries iniciais no desenvolvimento e aprendizagem de ciências das crianças. Ensaio - Pesquisa em Educação em Ciências, 8(2), 161-175.

Lorenzetti, L., \& Delizoikov, D. (2001). Alfabetização científica no contexto das séries iniciais. Ensaio - Pesquisa em Educação em Ciências, 3(1), 1-17.

Miguel, G. V. B. N. (2010). Temos bichinhos só na barriga? In: VII Mostra de Trabalhos “ABC na Educação Científica - Mão na Massa”. Retrieved from: http://www.cdcc.sc.usp. $\mathrm{br} / \mathrm{maomassa} / \mathrm{mostras} / 2010 /$ trabalhos/40.html.

Milandri, M. (2004). Children's' views of microbes, current beliefs about bacteria in Italian grade school children. The Pediatric Infectious Disease Journal, 23(12), 1077-1080.

Oliveira, G. (2000). Conceituando digestão na educação infantil. In Anais VII Encontro Perspectivas do Ensino de Biologia (pp. 755-757), São Paulo: FEUSP.

Prokop, P., Fančovičová, J. \& Krajčovičová, A.(2016). Alternative conceptions about Micro-organisms are influenced by experiences with disease in children. Journal of Biological Education, 50(1), 61-72.

Scarpa, D. \& Trivelato, S. L. F. (2001). Aula de ciências sob um olhar vygotskyniano e bakhtiniano: será que golfinho é peixe? In Atas III Encontro Nacional de Pesquisas em Educação em Ciências, São Paulo, Brasil. Retrieved from: http://abrapecnet.org.br/ atas_enpec/iiienpec/Atas\%20em\%20html/o30.htm\#o30

Simonneaux, L. (2000). A study of pupils' conceptions and reasoning in connection with microbes, as a contribution to research in biotechnology education. International Journal of Science Education, 22(6), 619-644.

Siry, C., Ziegler, G., \& Max, C. (2012). Doing science through discourse-in-interaction: Young children's science investigations at the early childhood level. Science Education, 96(2), 311-326.

Souza, M. V. A. R. (2009). Estudo de caso: diferentes visões sobre os microrganismos (Dissertação de Mestrado). Instituto de Bioquímica Médica, Universidade Federal do Rio de Janeiro, Brasil.

Teixeira, R. M., Furtado, P. G., \& Wille, N. J. (2005). Zoologia de aranhas para crianças da creche UFF. In Anais I Encontro Nacional de Ensino de Biologia e III Encontro Regional de Ensino de Biologia, Rio de Janeiro/Espírito Santo, Brasil.

Trivelato, J., Jr. (1995). Concepções de alunos sobre fungos e bactérias. Série Textos Pesquisas para o ensino de ciências, n. 6. São Paulo: FEUSP. 
Trivelato, J., Jr. (2005). Um obstáculo à aprendizagem de conceitos em biologia: Geração espontânea x biogênese. In. R. Nardi (Ed.), Questões atuais no Ensino de Ciências (pp. 77-84). São Paulo: Escrituras.

Tsai, C. C., \& Wen, M. L. (2005). Research and trends in science education from 1998 to 2002: A content analysis of publication in selected journals. International Journal of Science Education, 27(1), 3-14.

White, E., Elson, B., \& Prawat, R. (1980). Children's conceptions of death. Child Development, 49, 307-310.

Celi Rodrigues Chaves Dominguez

${ }^{\circledR}$ http://orcid.org/0000-0001-9639-9439

University of São Paulo

School of Arts, Science and Humanities (EACH)

Science Teacher Education Program (LCN)

São Paulo, Brazil celi@usp.br

Natalia Leporo

University of São Paulo

School of Arts Science and Humanities (EACH)

Science Teacher Education Program (LCN)

São Paulo, Brazil

natyleporo@gmail.com

Milene Tino De Franco

${ }^{\oplus}$ http://orcid.org/0000-0003-0837-2805

Butantan Institute, Immunogenetics Laboratory

São Paulo, Brazil

milene.franco@butantan.gov.br

Glaucia Colli Inglez

${ }^{\circledR}$ http://orcid.org/0000-0002-0101-4717

Butantan Institute, Museum of Microbiology

São Paulo, Brazil

glaucia.inglez@butantan.gov.br 
Viviane Maimoni Gonçalves

[1] http://orcid.org/0000-0002-0980-8116

Butantan Institute Center of Biotechnology São Paulo, Brazil

viviane.goncalves@butantan.gov.br

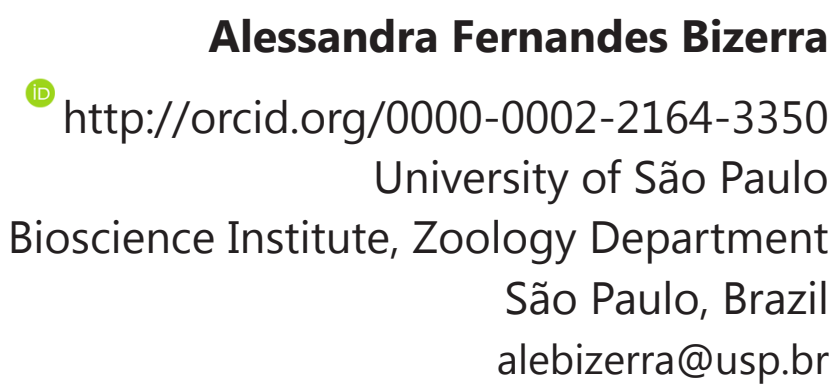

Submitted on 19th December 2016 Accepted on 20th December 2017 Published on 8th March 2018 